\section{Mortality by suicide: a focus on municipalities with a high proportion of self-reported indigenous people in the state of Amazonas, Brazil}

\section{Mortalidade por Suicídio: um enfoque em municípios com alta proporçãa de população autodeclarada indígena no Estado do Amazonas, Brasil}

\section{Jesem Douglas Yamall Orellana' \\ Paulo Cesar Basta" \\ Maximiliano Loiola Ponte de Souza'}

This study was carried out at the "Programa de Núcleos de Excelência - FAPEAM/ CNPq, project "Saúde e condições de vida de povos Indígenas na Amazônia" and had financial support from the Institute Brazil Plural.

'Instituto Leônidas e Maria Deane, Fundação Oswaldo Cruz - Manaus (AM), Brasil. "Escola Nacional de Saúde Pública Sergio Arouca, Fundação Oswaldo Cruz - Rio de Janeiro (RJ), Brasil.

Corresponding author: Maximiliano Loiola Ponte de Souza. Instituto Leônidas e Maria Deane, Fundação Oswaldo Cruz. Rua Terezina, 476, sala 201-F, Adrianópolis, CEP: 69057-070, Manaus, AM, Brazil. E-mail: maxkaelu@hotmail.com

Conflict of interests: nothing to declare.

\section{Abstract}

Objective: To analyze mortality rates and to describe the demographic and epidemiological characteristics of suicides recorded in the state of Amazonas. Methods: A descriptive and retrospective study has been carried out with emphasis on municipalities, which have shown, simultaneously, a high mortality rates and a high proportion of self-reported indigenous population, based on 2005 - 2009 data as provided by the Informatics Department of the Unified National Health System. Results: Among the general population of the state of Amazonas, the mortality rate, by suicide, of $4.2 / 100.000$ inhabitants has been reported, similar to that of Manaus (4.6/100.000 inhabitants). In contrast, at Tabatinga (25.2/100.000 inhabitants), at São Gabriel da Cachoeira (27.6/100.000 inhabitants) and at Santa Isabel do Rio Negro (36.4/100.000 inhabitants), municipalities, where the proportion of self-reported indigenous population is high, besides the taxes being notably higher, it was observed that most of the suicides has occurred among men; among young men aged between 15 - 24 years; at home; by hanging; during "weekend" and among the indigenous population. Discussion: Our findings have unveiled that suicide comes forth as a serious public health issue in some municipalities in the state of Amazonas, further indicating that the event occurs within very specific contexts, and that the dimension and the magnitude of the problem can be even more serious among populations or in territories exclusively inhabited by indigenous people.

Keywords: Epidemiology. Suicide. Indigenous health. Ethnicity. Health inequalities. Brazilian Amazon. 


\section{Resumo}

Objetivo: analisar as taxas de mortalidade e descrever as características demográficas e epidemiológicas dos suicídios registrados no Estado do Amazonas. Métodos: Realizou-se um estudo descritivo e retrospectivo com ênfase nos municípios que apresentaram, simultaneamente, elevadas taxas de mortalidade e elevadas proporções de população autodeclarada indígena, com base nos dados de 2005 - 2009 do Departamento de Informática do Sistema Único de Saúde. Resultados: Na população geral do Amazonas foi reportada taxa de mortalidade por suicídio de 4,2/100.000 habitantes, semelhante a de Manaus (4,6/100.000 habitantes). Em contraposição em Tabatinga (25,2/100.000 habitantes), em São Gabriel da Cachoeira (27,6/100.000 habitantes) e em Santa Isabel do Rio Negro (36,4/100.000 habitantes), municípios nos quais a proporção de população autodeclarada indígena é alta, além de taxas notadamente superiores, observou-se que a maioria dos suicídios ocorreu em homens; em jovens de 15 - 24 anos; no domicílio; por enforcamento; no "fim de semana" e em indígenas. Discussão: Nossos achados revelam que o suicídio desponta como um sério problema de saúde pública em alguns municípios do Amazonas, indicando ainda que o evento ocorre em um contexto particular e que a dimensão e a magnitude do problema possa ser ainda mais grave em populações ou territórios formados exclusivamente por indígenas.

Palavras-chave: Epidemiologia. Suicídio. Saúde indígena. Etnicidade. Desigualdades em saúde. Amazônia brasileira.

\section{Introduction}

In Brazil, during the past three decades, mortality, caused by external factors (violence, injuries, accidents etc.), has increased and caused significant impact on vital statistics. Lately, suicide has stood out in some regions as one of the main causes of death within this group of external factors ${ }^{1}$.

A recent study has demonstrated that, in Brazil, mortality rate by suicide of $4.8 / 100,000$ inhabitants, registered in 2008, is considered ${ }^{l o w}{ }^{2}$. However, the characteristics of mortality by suicide in the country present noticeable regional inequalities and variation in their distribution within groups of age, sex and ethnic origin ${ }^{3}$. More than the epidemiological relevance of mortality by suicide in some regions of the country, as well as the differences in the behavior, it is noticeable that the available studies on the theme are sparse and, in general, directed to the realities of the South and Southeast regions ${ }^{4-5}$.

In the North of Brazil, in the period 20042006, mortality rate by suicide was in the order of 4.3/100,000 inhabitants. Although this value could also be considered low, it still represents a number $60 \%$ higher than what was observed in 1980-1982 ${ }^{6}$. In the state of Amazonas, there are evidences pointing to the increase of mortality by suicide, especially among people younger than 60 years of age, from 1980 to $2005^{7}$.

The rare available studies on suicide in Amazonas were developed in specific contexts and/or confined to small geographical spaces, and point to the importance of suicide in indigenous populations ${ }^{8,10}$. A similar situation was reposted by a series of authors who indicate suicide as an important public health problem in ethnically differentiated populations, from various parts of the world ${ }^{11,14}$.

With the intention of widening knowledge regarding suicide in ethnically differentiated populations in Brazil, the objective of this study was to analyze the mortality rates and to describe demographic and epidemiological characteristics of the suicides registered in the state of Amazonas in the period 2005 - 2009. 


\section{Methods}

The state of Amazonas occupies an area of $1,559,161.682 \mathrm{~km}^{2}$, representing around $30 \%$ of the Legal Brazilian Amazon. Currently, nearly $20 \%$ of the self-reported indigenous population in Brazil lives in Amazonas, and little more than $30 \%$ of the total indigenous lands are demarcated and ratified. According to the last national census, the Amazonas population sums up to 3,483,985 inhabitants, among which, 4.8\% are self-reported indigenous populations, which is approximately 10 times bigger than the population registered in Brazil ${ }^{15}$. More than half of the Amazonian population lives in the capital Manaus and the remaining population is spread through the 61 municipalities left, considered to be small ${ }^{15}$.

A descriptive and retrospective study was carried out on mortality by suicide in the state of Amazonas for the period from 2005 to 2009, based on the data registered in the Mortality Information System Sistema de Informações sobre Mortalidade (SIM) - from the Informatics Department of the Unified National Health System Departamento de Informática do Sistema Único de Saúde (DATASUS), which has, as a primary source, information on Death Certificates - Declarações de Óbito (DO ${ }^{16}$.

In order to calculate the mortality rates, a death numerator was used, coded in twodigits interval, X60 to X84 (intentional selfinflicted injuries), from the International Statistical Classification of Diseases and Related Health Problems - Classificação Estatística Internacional de Doenças e Problemas Relacionados à Saúde (ICD-10) ${ }^{17}$. According to the $\mathrm{WHO}^{2}$, a denomination of population estimates those older than five years of age, from the national demographic census of 2000 and its respective census projections to the 2005 - 2009, was used $^{15}$, without any stratification of race/ color category.

From the total of 62 municipalities in Amazonas, those with high proportion of self-reported indigenous population (above $25 \%$ ) were selected. In the period studied, the capital Manaus focused approximately $50 \%$ of the state's population; from this, only $0.2 \%$ has self-reported as indigenous in the national census of $2010^{15}$. In spite of the low representation of self-reported indigenous people, Manaus was included in the analysis for comparison between the selected municipalities.

The mortality rates by suicide have been grouped in five categories: null (zero); low (0.1 to 4.9 deaths/100,000 inhabitants); medium (5.0 to 14.9 deaths/100,000); high (15.0 to 29.9 deaths $/ 100,000)$ and very high (30.0 or more deaths $/ 100,000)$, from the proposal of Diekstra and Gulbinat ${ }^{18}$.

The demographic profile of the people who committed suicide was carried out using the variables: sex, marital status, age and race/color. It should be borne in mind that the information field, race/ color, in the DO is filled through observation, since it is not possible for the corpses to identify themselves.

Alternatively, epidemiological characterization was performed according to the variables: locale of the event (house, hospital etc.), method used to commit suicide and day of the week on which the death occurred. The days of the week have been divided into weekend (Friday, Saturday and Sunday) and weekdays (from Monday to Thursday). The demographic and epidemiological characteristics were analyzed comparatively among the selected municipalities, the capital and the state.

The descriptive analysis of the data comprehended the relative, absolute and medium frequencies. The $\chi^{2}$ test was used for the comparison of proportions and the Mann-Whitney U one to compare the medians. The level of statistical significance considered was $\mathrm{p}<0.05$. The input of data and the respective analysis were done with the support of SPSS software, version 20.0. A map was built with the use of the application, ArcGis, version 9.3, on the mortality rates by suicide, having the 
municipalities of the state of Amazonas as special analysis units.

For being a study made from public knowledge data, available in the Health Minister's (Ministério da Saúde) official website, there was no need for submitting the same to the Research Ethics Committee (Comitê de Ética em Pesquisa).

\section{Results}

During the analyzed period, 615 deaths by suicide have been registered in the 62 municipalities in Amazonas. Of this, 75\% happened in the municipalities of Manaus (349), Tabatinga (50), São Gabriel da Cachoeira (45) and Santa Isabel do Rio Negro (18).

Mortality rate by suicide in Amazonas has been estimated in 4.2/100,000 inhabitants. In 34 municipalities (54.8\%), the mortality rates by suicide were considered low, including the capital Manaus $(4.6 / 100,000)$, and in 10 municipalities (16.1\%), they were considered medium. Two municipalities (3.2\%), São Gabriel da Cachoeira and Tabatinga, presented high mortality rates by suicide, with 27.6/100,000 inhabitants and $25.2 / 100,000$ inhabitants, respectively. In only one municipality (1.6\%), Santa Isabel do Rio Negro, the mortality rate by suicide was considered very high, 36.4/100,000 (Figure 1). In 15 municipalities (24.2\%), the rates were null, that is, there was no register of death by suicide.

From a total of 62 municipalities in Amazonas, nine (14.5\%) had a proportion of more than $25 \%$ of self-reported indigenous people in their population. From this subgroup, only São Gabriel da Cachoeira (76.6\%), Santa Isabel do Rio Negro (59.2\%) and Tabatinga (28.4\%) were included in the group of selected municipalities for analysis, for presenting both high and/or very high mortality rates by suicide and high proportion of self-reported indigenous population.

Although high or very high mortality rates by suicide had been observed in different age range groups in the selected municipalities, with the exception of those in the extremes of the age range, the higher values were registered among young people from 15 to 24 years of age. Among youngsters from the selected municipalities, mortality rates by suicide were considered very high, nearly 10 times superior to those observed in Manaus and in the state as a whole (Table 1).

Besides, among youngsters, suicide stood out as the main cause of death in Santa Isabel do Rio Negro, São Gabriel da Cachoeira, and Tabatinga, being responsible for over $25 \%$ of the deaths in these municipalities. In Amazonas as a whole and in Manaus, suicide did not show within the three main causes of death among youngsters (Figure 2).

Nearly $80 \%$ of all suicides registered in the selected municipalities and $20 \%$ in the state happened among people identified as indigenous in their death certificates (Table 2). However, in Manaus there were no registers of indigenous suicide.

In all the analyzed contexts, there was a prevalence of cases in male gender $(>80 \%)$ and in single people ( $>75 \%)$. The age median of the people who committed suicide in the selected municipalities (21 years of age) was significantly lower than that observed in Manaus (27 years of age) $(p=0.0001)$. More than three-fourths of the suicides happened in households, regardless of the analyzed context.

A lower suicide proportion was observed in hospitals in the selected municipalities $(5.3 \%)$, in comparison to Manaus (11.5\%), though of no statistical significance $(p=0.09)$. A significantly superior percentage of suicides ( $p$-value: 0.01 ) was observed during the weekends in the selected municipalities $(63.7 \%)$, when compared to Manaus (47.8\%). The main method used for committing suicide was hanging, both in the selected municipalities (91.1\%) and in Manaus (86.5\%), with no statistical difference $(\mathrm{p}=0.09)$. 


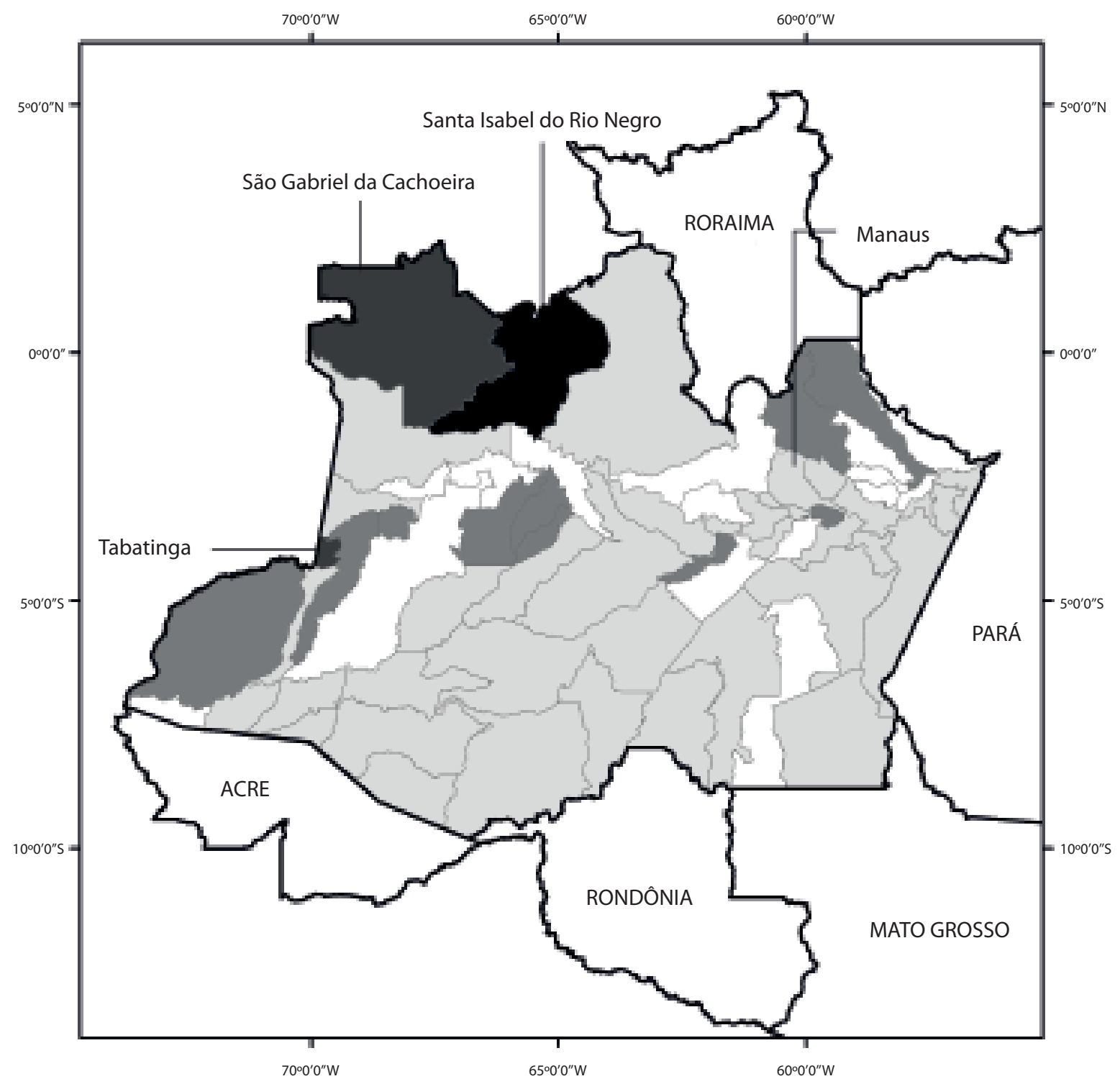

Federative units - Brazil

Suicide Mortality Rate / 100.000 inhabitants

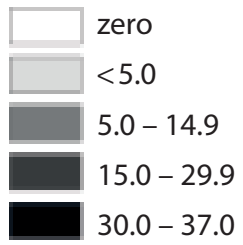<smiles>C[C@H]1CN1N</smiles>

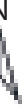

$275 \quad 137.5 \quad 0 \quad 275 \mathrm{Km}$

Source: Adapted from the System of Information about Mortality from Informatics Department of the Unified National Health System (DATASUS).

Fonte: Adaptado do Sistema de Informações sobre Mortalidade, do Departamento de Informática do Sistema Único de Saúde (DATASUS).

Figure 1 - Spatial distribution of suicide mortality rates in the municipalities of the State of Amazonas, Brazil, 2005 - 2009.

Figura 1 - Distribuição espacial das taxas de mortalidade por suicídio nos municípios do estado do Amazonas, Brasil, 2005 - 2009. 
Table 1 - Mortality rates suicide, by age group in the municipalities of Santa Isabel do Rio Negro, São Gabriel da Cachoeira, Tabatinga and Manaus, as well as the State of Amazonas, Brazil, 2005 - 2009.

Tabela 1 - Taxas de mortalidade por suicídio, segundo faixa etária, nos municípios de Santa Isabel do Rio Negro, São Gabriel da Cachoeira, Tabatinga e Manaus, assim como no Estado do Amazonas, Brasil, 2005 - 2009.

\begin{tabular}{lccccc}
\hline & $\begin{array}{c}\text { Santa Isabel } \\
\text { do Rio Negro }\end{array}$ & $\begin{array}{c}\text { São Gabriel } \\
\text { da Cachoeira }\end{array}$ & Tabatinga & Manaus & Amazonas \\
\hline $5-14$ years & 0.00 & 6.5 & 11.6 & 0.9 & 1.0 \\
$15-24$ years & 84.1 & 67.6 & 59.9 & 6.8 & 7.2 \\
$25-34$ years & 61.1 & 26.6 & 28.4 & 6.7 & 6.0 \\
$35-44$ years & 37.9 & 33.9 & 0.00 & 4.0 & 4.1 \\
$45-54$ years & 55.4 & 7.5 & 7.2 & 4.1 & 3.7 \\
$55-64$ years & 0.00 & 0.00 & 11.8 & 3.9 & 3.0 \\
65 years or + & 0.00 & 0.00 & 12.4 & 4.3 & 2.6 \\
Total & 36.4 & 27.6 & 25.2 & 4.6 & 4.2 \\
\hline
\end{tabular}

Source: Adapted from the System of Information about Mortality from Informatics Department of the Unified National Health System (DATASUS). Fonte: Adaptado do Sistema de Informações sobre Mortalidade, do Departamento de Informática do Sistema Único de Saúde (DATASUS).

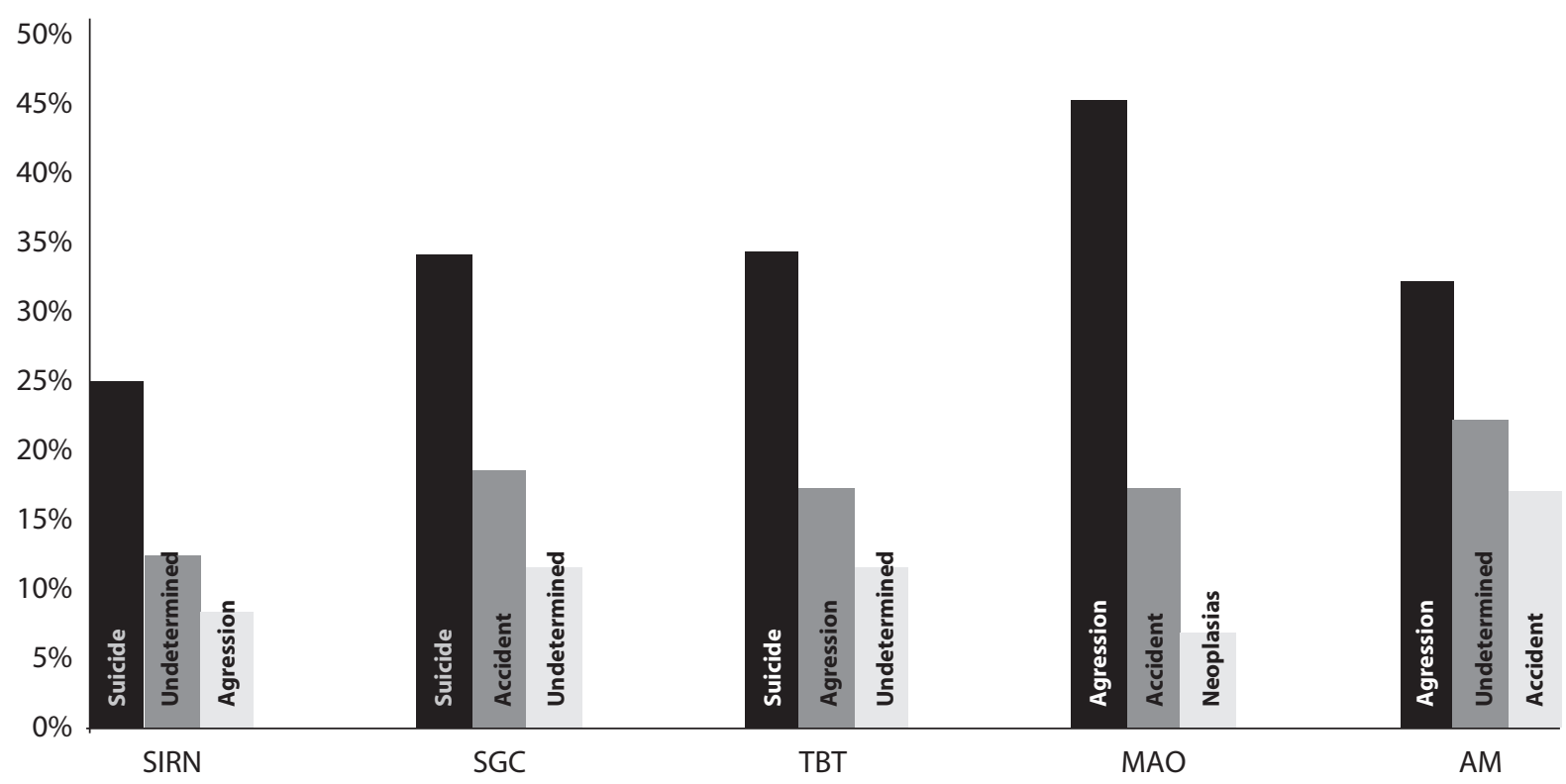

SIRN: Santa Isabel do Rio Negro; SGC: São Gabriel da Cachoeira; TBT: Tabatinga; MAO: Manaus; AM: Amazonas.

Source: Adapted from the System of Information about Mortality from Informatics Department of the Unified National Health System (DATASUS). Fonte: Adaptado do Sistema de Informação de Mortalidade do Departamento de Informática do Sistema Único de Saúde (DATASUS).

Figure 2 - Proportional mortality in youngs (15 to 24 years old) of Santa Isabel do Rio Negro, São Gabriel da Cachoeira, Tabatinga, Manaus and state of Amazonas, Brazil, 2005 - 2009.

Figura 2 - Mortalidade proporcional em jovens (15 a 24 anos) de Santa Isabel do Rio Negro, São Gabriel da Cachoeira, Tabatinga, Manaus e Amazonas, Brasil, 2005 - 2009. 
Table 2 - Demographic and epidemiological characteristics of deaths by suicide recorded in "selected municipalities" (Santa Isabel do Rio Negro, São Gabriel da Cachoeira, Tabatinga) in Manaus and the State of Amazonas, in the period 2005 - 2009.

Tabela 2 - Características demográficas e epidemiológicas dos óbitos por suicídio registrados nos municípios selecionados (Santa Isabel do Rio Negro, São Gabriel da Cachoeira, Tabatinga), em Manaus e no Estado do Amazonas, no período de 2005 - 2009.

\begin{tabular}{|c|c|c|c|}
\hline & $\begin{array}{l}\text { Selected Municipalities } \\
\qquad(n=113) \\
\%\end{array}$ & $\begin{array}{c}\text { Manaus } \\
(\mathrm{n}=349) \\
\%\end{array}$ & $\begin{array}{c}\text { Amazonas } \\
(\mathrm{n}=615) \\
\%\end{array}$ \\
\hline \multicolumn{4}{|l|}{ Race/color } \\
\hline Indigenous & 78.8 & 0.0 & 17.2 \\
\hline Brown & 20.4 & 86.5 & 71.7 \\
\hline Other & 0.8 & 8.9 & 8.5 \\
\hline Ignored & 0 & 4.6 & 2.6 \\
\hline \multicolumn{4}{|l|}{ Gender } \\
\hline Male & 83.2 & 82.5 & 82.9 \\
\hline Average age & 21 & 27 & 25 \\
\hline \multicolumn{4}{|l|}{ Marital status } \\
\hline Single & 79.5 & 77.4 & 78.9 \\
\hline Married & 12.5 & 13.5 & 12.8 \\
\hline Other & 3.6 & 5.4 & 4.6 \\
\hline Ignored & 4.5 & 3.7 & 3.7 \\
\hline \multicolumn{4}{|l|}{ Location } \\
\hline Household & 86.7 & 75.4 & 77.4 \\
\hline Hospital & 5.3 & 11.5 & 9.6 \\
\hline Other & 7.1 & 12.9 & 12.7 \\
\hline Ignored & 0.9 & 0.3 & 0.3 \\
\hline Weekend & 63.7 & 47.8 & 51.4 \\
\hline \multicolumn{4}{|l|}{ Suicide method } \\
\hline Hanging & 91.2 & 86.5 & 84.9 \\
\hline Poisoning & 5.3 & 3.2 & 4.7 \\
\hline Fire weapon & 2.7 & 6.6 & 7.6 \\
\hline Other & 0.9 & 3.7 & 2.8 \\
\hline
\end{tabular}

Source: Adapted from the System of Information about Mortality from Informatics Department of the Unified National Health System (DATASUS).

Fonte: Adaptado do Sistema de Informação de Mortalidade do Departamento de Informática do Sistema Único de Saúde (DATASUS).

\section{Discussion}

Though mortality rate by suicide had been low in the state of Amazonas, the disaggregated analysis of the data revealed important inequalities in the mortality pattern between and in the municipalities, with special attention to the elevated rates in the selected municipalities and the surprising frequency of deaths among individuals identified as indigenous on the information field for race/color, in death certificates.
Even if the selected municipalities are considered to be small and the sum of their populations represent only $3.1 \%$ of the total in Amazonas, among them $18.4 \%$ of the suicides in the state were registered, not only making clear the importance of the problem in the areas of Alto Rio Solimões (where Tabatinga is located) and Alto Rio Negro (where Santa Isabel do Rio Negro and São Gabriel da Cachoeira are located), but also confirming findings from previous studies on the theme in these areas ${ }^{9,10}$. The meaningful 
percent of self-reported indigenous people in these populations could explain, at least in parts, the fact that over three-fourths of the suicides were attributed to individuals identified as indigenous, according to the information field race/color in death certificates.

However, if we consider these municipalities as a group, the percentage of selfreported indigenous people is approximately $50 \%$, suggesting that, besides the ethnic formation, other factors possibly contributed to over-mortality among people identified as indigenous within these areas. Now, as it concerns Manaus, lack of registration on indigenous suicide could be a reflex of problems related to classification mistakes in the race/color information field in death certificates. In this sense, it is possible to consider that during identification of an indigenous corpse, victim of suicide, the health professional, making use of their logic for ethno-racial rating, have privileged the filling of the race/color information to "mulatto" in the death certificate.

Then again, it is necessary to remember that the percentage of self-reported indigenous people in Manaus is much inferior to those observed in the selected municipalities. In addition, there are indications of important differences between the rates and characteristics of suicidal death in Manaus and in the selected municipalities. The last two aspects suggest that the differences found in relation to the characteristics of suicide in Manaus and selected municipalities are not just a result of mistakes in classification of race/color information in death certificates, but that they could also be influenced, somehow, by some kind of specific vulnerability associated to ethno-racial and/ or socio-economic disadvantages.

In the selected municipalities, the most elevated mortality rates by suicide were registered among the group of youngsters from 15 to 24 years of age, which were, approximately, 10 times higher than those in Manaus and Amazonas. In accordance to that is the finding that the age median of the individuals who committed suicide in the selected municipalities was significantly lower than that observed in Manaus. Analogously, in indigenous populations, both in Brazil ${ }^{19}$, as in North America ${ }^{11,13}$, or in Oceania ${ }^{14}$, the act of committing suicide is characterized as a juvenile event, as opposed to what is frequently related in non-indigenous populations, in which is observed a progressive increase in mortality rates by suicide as aging progresses.

In general, in general population, older age groups are those that concentrate the highest mortality rates of suicide $e^{6,7,20}$. Thus, in the selected municipalities, suicide emerged as the leading cause of death among young people, different from what was observed in Manaus, in the Amazon and in other regions of Brazil and the world ${ }^{6-21}$.

In the selected municipalities, the percentage of suicide on weekends was significantly higher than what was observed in Manaus. Souza et al..$^{22}$, described changes in traditional alcohol consumption within the indigenous context in the Alto Rio Negro, meaning, weekends begin to be seem as trivial and propitious moments for the consumption of alcoholic beverages.

Souza and Orellan $\mathrm{a}^{10}$ in a study on mortality by suicide in São Gabriel da Cachoeira, supported by the ethnographic findings of Souza et al..$^{22}$, suggest a possible relation between the elevated frequency of suicides on weekends and the consumption of alcoholic beverages. Although the concomitant use of alcohol and suicide is not an exclusive indigenous behavior ${ }^{23}$, the ingestion of alcohol has been pointed out, in literature, as associated to suicide in ethnically differentiated groups ${ }^{24}$.

Another aspect in the characteristics of suicide in the chosen municipalities, when compared to Manaus, was the elevated occurrence of these events in households as opposed to hospital environments.

In general, in situations in which suicide is committed by most lethal methods, death tends to happen out of the hospital environment, since the individuals die in the site of the event due to the gravity of the injuries, even before they could be directed 
to health care services ${ }^{25}$. In the investigated context, the higher rate of domestic deaths by suicide within the selected municipalities, in comparison to Manaus, seems to be associated with other factors, since there was no difference related to the lethal efficiency of the method used for the suicide, once hanging has stood out as the most common method used for suicide, in both contexts.

The lower capacity of the specialized health services installed in the selected municipalities, in addition to the long distances to be covered, especially in cases where suicide has occurred in rural areas, could explain, at least in parts, the difference observed.

The similarity between the profile of people who committed suicide in the selected municipalities and of those in Manaus, with regard to bigger proportions of men and single people, shows nothing out of the expected. Apart from some exceptions, as in some Asian contexts, in which married women commit suicide the most ${ }^{26}$, the preponderance of single men among suicidals is common in almost all the investigated scenarios ${ }^{25}$.

In this study, it was possible to verify the establishment of a direct relation between the high proportion of the selfreported indigenous population and the elevated rates of mortality by suicide does not seem completely adequate, since in six other municipalities, the high proportion of indigenous mortality by suicide was not expressive.

Alternatively, it was also made evident that the characteristics of mortality by suicide in the selected municipalities are very similar to those of other indigenous contexts, in the United States, Canada, Australia and New Zealand. In these localities, investigations indicate that suicides would frequently be associated with biological factors $^{27}$, issues related to access, quality of services offered to the population and private aspects of the socio-cultural organization of the studied groups ${ }^{27-30}$.
It is also important to remember that the vital statistics data, including mortality, are produced in the routine of the official health services. This way, the information available on the occurrence and causes of death are related to higher or lower capacity of these services. Thus, areas poorly served and with lesser monitoring capacity of the health conditions of the population tend to produce information also of lower quality. In other words, possible asymmetries in the quality of services offered to the population could influence the collection, analysis and dissemination of data on mortality. This, according to Laurenti et al. ${ }^{31}$, could distort, somehow, the data used to calculate the estimation of mortality rates, especially by suicide.

Regarding the socio-cultural aspects, the fact that the phenomenon of suicide in indigenous peoples is complex cannot be ignored. Aho and $\mathrm{Liu}^{32}$ delimited the possible deleterious influence in the set of violence suffered during the long process of colonization in higher or lower suicide rates among native population. Hunter et al. ${ }^{29}$ and Silviken ${ }^{33}$ draw attention to the importance of the way indigenous people, over time, also deal with asymmetrical relations established with non-indigenous society for the comprehension of suicide. Other aspects considered relevant to the comprehension of this theme refer to the way how, nowadays, relations are established among different generations, access to alcoholic beverages as well as the local mechanisms of controlling this consumption ${ }^{24}$.

It is possible that, somehow, the aspects discussed above, and other non-identified ones, articulate themselves, configurating contexts more or less favorable to suicide and for the reporting of this event. These diverse contexts alone could explain the variations in the mortality rates registered in different municipalities with high proportion of self-reported indigenous population, indicating the need of subsequent detailed investigations, articulating epidemiological strategies to ethnographic 
and epidemiologic strategies and ethnographic approaches appropriated to reality in Amazonas.

Besides, this study had to deal with an additional challenge, for the demographic census from IBGE, used to select the municipalities of Santa Isabel do Rio Negro, São Gabriel da Cachoeira and Tabatinga, relies upon the approach of self-report to classify the population based on race/color, while the Information System of Mortality, using data from the death certificates, present data related to race/color, which is derived from the hetero-classification strategy. However, any excess concerning the suicidal theme, coming from this investigation, should be interpreted with caution.

It should be emphasized that, despite the inherent limitations of data produced in the context of health services, especially in relation to the data quality and the coverage of information systems, studies based on secondary data tend to be of low cost, of rapid operationalization and to have the potential to generate information that can delineate the epidemiological profile of specific aggravations, and also provide to (re)orient policies and specific actions in areas of health ${ }^{31}$.

Therefore, at least to the initial approach, we understand that investigations of this nature arise as valuable sources of information, especially when such knowledge is restricted and its comprehension implies remarkable operational and theoreticalmethodological challenges ${ }^{34}$, such as, for instance, the phenomenon of suicide in the Amazonian indigenous context.

One of these challenges consists in seeking ways to access the symbolic meanings suicide takes in the specific investigated context. This is an important element to a wider comprehension of this phenomenon. In this sense, Hamlin e Brym ${ }^{35}$ analyzing a set of ethnographic data of the Guarani-Kaiowá, points out the weaknesses of the theoretical formulations of Durkheim, classically used as the key to explain suicide as a social phenomenon in non-indigenous contexts. Keifenheim ${ }^{36}$ analyzes the Kashinawa from the Brazilian Amazonia, presenting in a detailed way, the intrinsic correlation between the cosmological conceptions of the group and the way in which the dying process can be comprehended, in general, and the process of dying by suicide, in particular.

A last aspect to receive some attention is that the design of this study does not allow the making of any inference about the context or the motives which led people, particularly individuals classified as indigenous, into committing suicide. In the field of suicide epidemiology, studies which seek to investigate these aspects, make use of tools called psychological autopsy. Researches using similar tools in European and North American countries have been pointing to, for example, a high prevalence of mental disorders in suicide victims, supporting public policies of expansion in mental health assistance as a strategy to prevent suicide ${ }^{37}$.

Alternatively, studies carried out in non-Western environments, such as rural China, in which there is a predominance of juvenile suicides committed in an impulse as an answer to interpersonal conflicts, have identified a low prevalence of mental disorders among those who took their own lives ${ }^{38,39}$.

These findings question the limits of broadening the coverage of mental health care as a universal strategy against suicide, especially in contexts in which death by suicide can acquire particular meanings, influenced by specific symbolic systems and by those which are operative in contemporary urban-Western settings.

Thus, it is understood that future actions against suicide in the selected municipalities must take into account the issues discussed here-especially, if the juvenile character of suicides is found, and if the evidence, obtained in other contexts, points to the importance of interpersonal conflicts in the composition of the complex scenario of indigenous suicide ${ }^{8}$. 


\section{Conclusions}

In the analyzed period, although the mortality rate by suicide observed in the state of Amazonas has been considered inferior to those reported in other localities, the finding of high and/or very high levels in the municipalities of Santa Isabel do Rio Negro, São Gabriel da Cachoeira and Tabatinga, as well as the identification of a profile characterized by predominantly indigenous people, deserves attention, both from health authorities as well as from the scientific community.

Such findings point not only to the existence of a serious public health problem, in a peculiar social and sanitary context in especially vulnerable populations, but also to the possibility that this socioepidemiological scenario can be even more severe in populations or territories formed exclusively by ethnically differentiated indigenous groups, as observed by Coloma ${ }^{19-40}$ between the Guarani Kaiowá and Nandeva residing in Mato Grosso do Sul, in the Middle-West region of Brazil.

Finally, we advocate the need for researches, preferably with the involvement of local health care services, with indigenous participation, using inspired methodology in instruments like "psychological autopsy", in order to apprehend, even in an exploratory way, the contexts and motivations of suicide, in the search for changing strategies, culturally sensitive to the socio-cultural and sanitary local scenario.

\section{References}

1. Reichenheim ME, Souza ER, Moraes CL, Mello-Jorge MHP, Silva CMFP, Minayo MCS. Violence and injuries in Brazil: the effect, progress made, and challenges ahead. Lancet 2011; 377: 1962-75.

2. World Health Organization. Country reports and charts Web page. Disponível em: http://www.who.int/mental_health/ prevention/suicide/country_reports/en/index.html (Acessado em 01 novembro de 2011).

3. Bertolote JM, Botega $\mathrm{N}$, de Leo D. Inequities in suicide prevention in Brazil. Lancet 2011; 378: 1137.

4. Macente LB, Zandonade E. Estudo da série histórica de mortalidade por suicídio no Espírito Santo (de 1980 a 2006). J Bras Psiquiatr 2011; 60(3): 151-7.

5. Meneghel SN, Victora CG, Faria NMX, Carvalho LA, FalkJW. Características epidemiológicas do suicídio no Rio Grande do Sul. Rev Saúde Pública 2004; 38(6): 804-10.

6. Lovisi GM, Santos AS, Legay L, Abelha L, Valencia E. Análise epidemiológica do suicídio no Brasil entre 1980 e 2006. Rev Bras Psiquiatr 2009; 31(Suppl 2): 86-93.

7. Brzozowski FS, Soares GB, Benedet J, Boing AF, Peres MA. Tendência temporal do suicídio no Brasil no período 1980-2005. Cad Saúde Pública 2010; 26(7): 1293-302.

8. Poz JD. Crônica de uma morte anunciada: do suicídio entre os Sorowaha. Rev Antropol 2000; 43(1): 89-144.

9. Erthal RMC. O suicídio Tikúna no Alto Solimões: uma expressão de conflitos. Cad Saúde Pública 2001; 17(2): 299-311.
10. Souza MLP, Orellana JDY. Suicide mortality in São Gabriel da Cachoeira, a predominantly indigenous brazilian municipality. Rev Bras Psiquiatr 2012; 34(1): 34-7.

11. Malchy B, Enns MW, Young TK, Cox BJ. Suicide among Manitoba's aboriginal people, 1988 to 1994. Can Med Assoc J 1997; 156: 1133-8.

12. Olson LM, Wahab S. American Indians and Suicide: A Neglected Area of Research. Trauma Violence Abuse 2006; 7(1): 19-33.

13. Mullany B, Barlow A, Goklish N, Larzelere-Hinton F, Cwik M, Craig M, et al. Toward Understanding Suicide Among Youths: Results From the White Mountain Apache Tribally Mandated Suicide Surveillance System, 2001-2006. Am J Public Health 2010; 99(10): 1840-8.

14. Silburn S, Glaskin B, Henry D, Drew N. Preventing Suicide Among Indigenous Australians. In: Purdie N, Dudgeon P, Walker R, editors. Working Together: Aboriginal and Torres Strait Islander Mental Health and Wellbeing Principles and Practice. Canberra: Office of Aboriginal and Torres Strait Islander Health, Department of Ageing; 2010. p. 91-104.

15. IBGE - Instituto Brasileiro de Geografia e Estatística. População: censos demográficos. Disponível em http://www. ibge.gov.br/home/mapa_site/mapa_site.php\#populacao (Acessado em 15 junho de 2011).

16. DATASUS. Departamento de Informática do Sistema Único de Saúde. Informações de Saúde. Disponível em http:// www2.datasus.gov.br/DATASUS/index.php?area=02 (Acessado em 16 julho de 2011). 
17. Organização Mundial da Saúde. Classificação estatística internacional de doenças e problemas relacionados à saúde, 10ª revisão. 2a ed. São Paulo: EDUSP; 1995.

18. Diekstra RFW, Gulbinat W. The epidemiology of suicidal behaviour: a review of three continents. World Health Stat Q 1993; 46(1): 52-68.

19. Coloma C, Hoffman JS, Gawryszewski VP, Crosby AE. Suicide Trends and Characteristics Among Persons in the Guaraní Kaiowá and Ñandeva Communities - Mato Grosso do Sul, Brazil, 2000-2005. MMWR Morb Mortal Wkly Rep 2007; 56(1): 7-9.

20. Liu IC, Liao SF, Lee WC, Kao CY, Jenkins R, Cheng ATA. A cross-ethnic comparison on incidence of suicide. Psychol Med 2011; 41(6): 1213-21.

21. DeLeo D, Bertolote J, Lester D. Self-directed violence. In: Krug EG, Dahlberg LL, Mercy JA, Zwi AB, Lozano R, editors. World report on violence and health. Geneva: World Health Organization; 2002. p. 185-212.

22. Souza MLP, Deslandes SF, Garnelo L. Modos de vida e modos de beber de jovens indígenas em um contexto de transformações. Cien Saude Colet 2010; 15(3): 709-16.

23. Landberg J. Alcohol and suicide in eastern Europe. Drug alcohol Rev 2008; 27: 361-73.

24. Calabria B, Doran CM, Vos T, Shakeshaft AP, Hall W. Epidemiology of alcohol-related burden of disease among Indigenous Australians. Aust N Z J Public Health 2010; 34(Suppl 1): 47-51.

25. Hawton K, van Heeringen K. Suicide. Lancet 2009; 373: 1372-81.

26. Wei KC, Chua FC. Suicide in Asia. Int Rev Psychiatry 2008; 20(5): 434-40.

27. Marusic A, Farmer A. Genetic risk factors as possible causes of the variation in European suicide rates. Br J Psychiatr 2001; 179: 194-6.

28. Kosky RJ, Dundas P. Death by hanging: implications for prevention of an important method of youth suicide. Aust New Zealand J Psychiatr 2000; 34(5): 836-41.

29. Hunter E, Harvey D. Indigenous suicide in Australia, New Zealand, Canada, and the United States. Emerg Med 2002; 14(1): 14-23.
30. Tobias M, Blakely T, Matheson D, Rasanathan K, Atkinson J. Changing trends in indigenous inequalities in mortality: lessons from New Zealand. Int J Epidemiol 2009; 38(6): 1711-22.

31. Laurenti R, Mello-Jorge MHP, Gotlieb SLD. Mortalidade segundo causas: considerações sobre a fidedignidade dos dados. Rev Panam de Salud Publica 2008; 23(5): 349-56.

32. Aho KLT, Liu JH. Indigenous Suicide and Colonization: The Legacy of Violence and the Necessity of Self-Determination. Int Journal of Conflict and Violence 2010; 4(1): 124-33.

33. Silviken A. Prevalence of suicidal behavior among indigenous Sami in northern Norway. Int J Circumpolar Health 2009; 68: 204-11.

34. Hjelmeland H. Cultural Context Is Crucial in Suicide Research and Prevention. Crisis 2011; 32(2): 61-4.

35. Hamlin CL, Brym RJ. The return of the native: a cultural and social-psychological critique of Durkheim's suicide based on the Guarani-Kaiowá of southwestern Brazil. Sociological Theory 2006; 24(1): 42-57.

36. Keifenheim B. Suicide 'à la Kashinawa'. Le désir de l'au-delà ou la séduction olfactive et auditive par les esprits des morts. Journal de la Société des Amérinistes 2002; 88: 91-110.

37. Phillips MR. Rethinking the Role of Mental Illness in Suicide. Am J Psychiatry 2010; 167(7): 731-3.

38. Yang GH, Phillips MR, Zhou MG, Wang LJ, Zhang YP, Xu D. Understanding the unique characteristics of suicide in China: national psychological autopsy study. Biomed Environ Sci 2005; 18(6): 379-89.

39. Zhang J, Xiao S, Zhou L. Mental disorders and suicide among young rural Chinese: a case-control psychological autopsy study. Am J Psychiatry 2010; 167(7): 773-81.

40. Coloma CJ, Hoffman J, Crosby A. Suicide Among the Guarani Kaiowá and Nandeva in Mato Grosso do Sul, Brazil. Arch Suicide Res 2006; 10(2): 191-207.

Received on: 01/10/12 Final version presented on: $12 / 17 / 12$ Accepted on: 01/16/13 